\title{
Customers' Driven Green Supply Management and Organization Performance
}

\author{
Asad Ullah Shah ${ }^{*}$, Danish Ahmed Siddiqui ${ }^{2}$ \\ ${ }^{1}$ Research Scholar, Karachi University Business School, University of Karachi, PAKISTAN \\ ${ }^{2}$ Associate Professor, Karachi University Business School, University of Karachi, PAKISTAN \\ Corresponding Contact: \\ Email: asad.s.ullah@gmail.com
}

Manuscript Received: 21 June 2019 - Revised: 09 August 2019 - Accepted: 29 August 2019

\begin{abstract}
The purpose of this study is to identify the impact of various elements of customers' driven green supply chain management such as internal green supply chain management, environmental collaboration with customers and environmental monitoring of suppliers over the environmental performance of an organization. For the purpose of this research, a survey was conducted in Karachi from the individuals involved in manufacturing and service providing industries. The survey was conducted using a questionnaire. The results indicated that all variables studied in this research including internal green supply chain management, environmental collaboration with customers' and environmental monitoring of suppliers' positively affect the overall environmental performance of a firm. An organization can enhance its environmental performance by effectively applying the strategies for green supply chain management. Green supply chain management has become a critical aspect in the current era as it has emerged as most vital attribute to sustainable environment.
\end{abstract}

Key Words: green supply chain management, environmental, suppliers, performance sustainability, Pakistan

\section{INTRODUCTION}

\section{Background to the Study}

In the modern era of globalization and competitive environment, the survival of any organization is highly dependent on the overall performance of all functions and departments. Therefore, it has become a vital challenge for every organization to achieve excellence in each activity performed by it. Supply chain management creates the need of integration and synchronization of business processes and strategy positioning throughout the supply chain so as to be able to satisfy the end consumers of the supply chain. Business processes that must be integrated and synchronized include procuring, producing, selling \& marketing, distribution \& logistics, and information systems. Strategic requirements that need to be aligned include customer concentration, efficiency, quality, and responsiveness and most recently environmental sustainability. Environmental sustainability is a supply chain 
imperative rather than an organizational imperative. Development of environmentally friendly processes, products, and services requires a unified effort by all members of the supply chain to avoid sub-optimization at the partner level. Manufacturing organizations have begun to implement green supply chain management (GSCM) practices in response to customer demand for products and services that are environmentally sustainable and that are created through environmentally sustainable practices and in response to governmental environmental regulations. These practices require that manufacturers work in concert with suppliers and customers to enhance environmental sustainability. It has become necessary for every organization to focus on environmental concerns of its stakeholders. It has increased the importance of relationships with external partners in order to be more effective in achieving environmental sustainability. The forward and backward integration in the form of green supply chain management has become a vital aspect for every organization in the competitive environment.

Organizations all around the world are constantly working to develop different and innovative methods to increase their competitiveness. Bacallan (2000) proposed that more quite of these organizations are increasing their competitiveness through developments and enhancement in their environmental performance to fulfill the increasing environmental regulations, to cope up with the environmental concerns of their stakeholders specially their customers, and to minimize the environmental impact of their production and service activities. Green supply chain management as a form of environmental improvement is an operational initiative that many organizations are adopting to address such environmental issues. It is commonly observed that green supply chain management encourages efficiency and collaboration between business partners and their lead organizations, and helps to improve environmental performance, mitigate waste and enable cost reduction. This collaboration is likely to improve the corporate image, competitive advantage and marketing exposure.

\section{Problem Statement}

Balancing economic and environmental performance has become increasingly important for organizations facing competitive, regulatory, and community pressures. With increased pressures for environmental sustainability, it is expected that enterprises will need to implement strategies to reduce the environmental impacts of their products and services. Customers and governmental entities have begun to demand that processes, products, and services be environmentally friendly, it is important that managers identify and implement environmental sustainability practices that extend throughout the supply chain.

In the current era, a large number of organizations identify their supply chain partners as coaccountable in green and sustainable management. The requirement to have a large and broader perspective of green and sustainable management from a broader social system and value chain view is identified in the business literature as green supply chain management, and in the field of environmental sciences as a whole life cycle management of products. This move toward sustainable supply chain management refers to the recognition of the joint environmental and socio-ethical impacts of supply chain partners throughout all the supply chain processes and the development of strategies to improve those processes. Firms can adopt sustainability-related rules and criteria in selecting and evaluating the performance of their suppliers, while would-be customers apply their own criteria. Customers' role in sustainability is growing, as advances of the social internet empower consumers and social communities to actively participate and massively collaborate in sustainable practices. Such developments facilitate and foster the development of a fourth-generation framework of sustainable supply chain management-one that incorporates the customers' role in 
sustainability across all supply chain operations. In Pakistan it has become a new challenge for all organizations to comply with the regulatory and social requirements of contributing to sustainability in the country. The goodwill of an organization is highly dependent on the sustainable activities performed by the organization. Therefore, the firms in Pakistan are striving hard to enhance their environmental performance so as to be able to comply with the customers' requirement as well as social responsibility. Green supply chain management is a relatively new phenomenon in developing countries like Pakistan however, organizations are taking challenging steps for practicing green supply chain management activities in their overall functional and operational activities.

\section{Gap Analysis}

One of the significant researches on green supply chain management was done by Laari et al. (2015) focused on identifying the impact of customer driven green supply chain on overall performance of an organization. It included various variables such as internal green supply chain management, environmental collaboration with customers, environmental collaboration with suppliers, environmental monitoring of customers and environmental monitoring of suppliers. However, major limitation was that it was done on a developed country hence didn't capture the dynamics in developing country. Moreover, that research is limited to the only huge manufacturing firms while in this research SME firms are also included. This is also mentioned in the study of (Hall, 2000; Lee \& Klassen, 2008).

In Pakistan, Ubaidullah Mumtaz , Yousaf Ali, Antonella Petrillo (2018), focused on the basic elements and factors including the effects of Green Supply Chain Practices on Economical, operational and financial performances of the local manufacturing firms, here we finds that the study ignores few most important factors of today`s market, one of the factor is customer demand i.e, today`s Green Supply Chain practices is basically driven on the customer demands which is addressed in this study, and the second factor is SCM through Supplier \& $3^{\text {rd }}$ party supply management which is also addressed in this study. Syed Abdul Rehman Khan1 \& Dong Qianli (2017), also focused on the basic environmental practices which are (green manufacturing, green purchasing, and cooperation with customers, eco-design, and green information systems) one of the basic factor they ignored was Supplier management in GSCM, Hence we included this in our study.

Similarly a research was conducted in India by Sunil Dhull1 \& M. S. Narwal1 (2017), about the Green supply chain drivers prioritization in the manufacturing industries by using the Fuzzy Topsis Method, this technique is widely used and accepted method this technique is incapable to work in the uncertain and vague decision making process. (Yu 2002). A study on the similar topic is also presented by, Md. Saifur Rahman, Md. Hasan Ali, A.S.M. Tariq Hoque (2017) in Bangladesh, which focused on the cost mitigation and the environmental Impact reduction on the basis of Green supply chain management concepts. However, this study is limited mainly to the cost management and focuses on the Green Supply Chain Practices only including Green Purchasing, Green Manufacturing, Green Distribution, and Forward Logistics. Moreover, there samples were taken from large firms only. And since developing country is mainly driven by SME sector, making their effect more pronounced hence, creating a significant gap in literature. And this study mainly attempted to fill that.

\section{Research Objectives and Significance}

It is important in the present era that the organizations in any country work according to the regulations related to environmental sustainability, moreover, it has become mandatory for the organizations to participate in environmental sustainability in order to have a positive 
goodwill of their entities. Customers focus more on the environmental sustainability of the organizations and how the organizations contribute to the environmental sustainability. Therefore, it is extremely important for the firms working in Pakistan to identify the variables that helps the firms to achieve environmental sustainability. The purpose of this research is to make available the assessment of Green Supply Chain Management practices and execution and to recognize the research prospects in it. The paper approaches in the direction of the recent literature available related to Green Supply Chain Management. The literature requires to focus on aspects of Green Supply Chain Management like Practices, implementation its performance, and analysis etc. Based on the literature the review is constructed to find the key research topics, interrelations and alliance patterns. The work involves the study of practices, implementation and the recent development in the field of Green Supply Chain Management, to get the areas where the Green Supply Chain Management can be applied. This research will provide the organizations with the variables that helps the organizations to enhance their performance and to contribute in environmental sustainability

\section{Research Question}

In line with the objective of this research, the main focus of this study is to identify the relationship of various variables studied in this research i.e. internal green supply chain management, environmental collaboration with the customers and environmental monitoring of suppliers; with the environmental performance of an organization. This study focuses on identifying the impact and significance of these variables on the overall environmental performance of the organizations and the contribution of the organizations in overall environmental sustainability in the country.

\section{LITERATURE REVIEW}

Various researchers have studied the concept of environmental sustainability as a framework for reviewing management practices in the operational and strategic backgrounds. Environmental sustainability has become a vital parameter in the measurement of overall performance of any organization. The success or failure of any organization in the current scenario in specifically dependent on the measure it takes for achieving excellence in sustainable practices. A main component within green supply chain management is concerned with inter-organizationally sharing responsibility for various aspects of environmental performance. Green supply chain management should encourage the sharing of environmental responsibility and lend itself to achieving a reduced environmental burden caused by industry. Sarkis and Kitazawa (2000) proposed that the proficiencies in total quality management (TQM) can comfort the introduction of pollution inhibition plans and programs and aptitudes in cross-functional management enable product stewardship, necessary for green supply chain management, and are connected with organizational proficiencies, capabilities and burdens existing for green supply chain management introduction.

It has been a challenge, together with the prospect, for manufacturing and service-oriented organization is to encounter the customer needs and demands and to achieve the customer participation in service operations without compromising on the overall service quality provided by the firms and by at the same time achieving the organizations' overall financial and strategic goals. One of the major issues in the achievement of cooperation with the customers is that customers normally perceive the sustainability with detriments of time, money, or comfort, and for this matter the customers' adoption of these trade-offs is a necessary requirement for the achievement of sustainability (McKercher and Prideaux 2011). 
It can lead to wastages and underutilization of resources that are the major obstacles in achieving sustainability. Kassinis and Soteriou (2003) argued that customers can actively contribute in the supply chain activities and processes of the firms providing tourism facilities, and research targeting to study and explore the role of the customers in overall service sustainability should adopt a green supply chain management methodology. Sarkis (2003) presented a green supply chain management model for studying and exploring the role of the customers' in achieving sustainability at all supply chain management activities and processes, it uses a functional life cycle method for recognizing manners to manage environmental effects for all supply chain activities and processes, including procurement, production, distribution, marketing, service design and consumption. Another important element in achieving excellence in environmental sustainability is the customer awareness and education in designing and demanding sustainable services can make the firms to adopt to such sustainable practices and services. Sustainable service design includes framing of extensive service models such as multi-user or shared-use products in product-service combination.

People or social networks may likewise end up maintainable business visionaries through grassroots advancement, as they produce supportable improvement arrangements that react to the neighborhood circumstance, and the interests and estimations of the networks included (Seyfang and Smith 2007; Wagner 2012). Although a number of studies explore the role of customer participation in invention and innovation, for instance by crowd-sourcing, cocreation, user-innovation, virtual customer integration, and open innovation.

Sigala (2012) studies the reusing or reuse of workers' and clients' assets is a critical manner by which clients can give assets to supporting economical acquirement. Research is required around there to explore the kind of administration systems and coordinated effort methodologies that organizations can create for ingraining, rousing, and better dealing with the assets that their clients are eager to give. One of the sustainable activities in the production-oriented industry is the reduction in waste and usage of resources (Sarkis 2003), but an issue that usually encountered due to the unpredictability, inadequacy, and uncertainty introduced by the customer's participation. Thus, service firms should aim to manage customer behavior in the production process, for example, by rewarding behavior that supports sustainable production. Sener and Hazer (2008) proposed that customers can share their comments and feedback about the production processes of firms by using social internet tools (e.g., blogs, wikis, social networks, online forums). Firms can in turn identify and exploit this user-generated content for identifying ways to improve their sustainable production practices

In order to inspire the customers' environmentally friendly consumption choices, organizations are required to implement practices that encourage overall sustainability and that leads to the production of green products and services. Sheth, Sethia, and Srinivas (2011) proposed various activities that can be used by the organizations to encourage green consumption of the customers which includes tangible rewards for the customers, intrinsic rewards for the customers, promotion of recycling and contribution of the customers for the recycling, de-promotion of non-environmentally friendly products and services, and other activities that leads to promote customer behavior for sustainable practices and green environment. HervéHoudré (2008) summarized the contributions of customers in enabling a sustainable supply chain processes and activities in tourism industry, by analyzing the existing researches and exploring the customers' behavior. The green supply chain management notion encompasses a context for the sustainable role of consumers in overall 
supply chain activities and processes. This context suggests that consumers and their social groups can contribute to green supply chain management in all processes, including, designing, manufacturing, purchasing, logistics, promotion, and marketing, as well as reverse logistic activities and getting feedback from the customers.

Christmann and Taylor (2001) proposed that foreign trade of any organization i.e. export and sales to customers in other countries are the main forces for enhancing the environmental performance of the organization. In the present era, firms in numerous countries are facing tremendous pressures for environment friendly products, services and processes while dealing in exports. Many researchers conclude that awareness for sustainable environment is increasing in all countries including developing countries which is enforcing the applicability of green processes around the organization to meet the environmental requirements in order to retain their positions in the markets. Chan and Lau (2001) studied the procurement behavior of several countries and compared green procurement attitude of Chinese and American customers, and it was concluded in the research that American customers have more preference for green procurement. Never the less, Chinese customers, particularly young customers have an increasingly high preference for green products and services and the awareness regarding sustainable environment in increasing day by day. Green supply chain management offers the organizations a chance to become the leaders in adopting green supply chain processes and activities and to gain a tremendous advantage over their competitors by proactively following green practices. Preuss $(2001,2002)$ analyzed the importance of integration of organization's internal network with the external information in order to implement the environmental strategies of the organization. He concluded that the organization can gain a multiplier effect of enforcing sustainable practices by partnering with its supply chain partners in order to implement green supply chain practices.

Laari et al. (2015) conducted a research for evaluating the organizational performances including financial performance and organization performance that results from the green practices followed by an organization. The study was focused on identifying the variables that directly or indirectly influence organizational financial performance and environmental performance. It was concluded from the findings of the research that an organization can enhance its performance both financially and environmentally by practicing green supply chain management. The customers of any organization can be a source of achieving high environmental performance and to contribute to sustainable environment as the pressure from the customers for apply green practicing can lead to high environmental performance of a firm. The research contradicts with the previous view of researchers that only internal green supply chain practices are the source of performance enhancement for any organization but it proposed that the customers and suppliers are effective enablers of environmental performance of any organization. Zhu et al. (2012) concluded that the nonexistence of strong relationship between green supply chain management practices and performance enhancement is a hindrance for producers in search of justifying green supply chain management implementation.

According to Yu et al., (2014) in the present era, green supply chain management (GSCM) has been emerged as combination of management of both upstream and downstream supply chain having the capacity and capability to curtail environmental effects. Lee et al., (2014) concludes that it is fundamental for any organization to work in a collective manner in order to achieve excellence in achieving environmentally friendly results and to build environmental relationships with its stake holders including suppliers and customers so as to be able to work in the direction of the targets for achieving the said results. Furthermore, 
monitoring of the suppliers while entering in any transactions is extremely important for the organizations now a days as the procuring company needs to evaluate its suppliers thoroughly in respect of its environmental commitments and the selection of any supplier should be focused on its environmental monitoring. Zhu et al. (2013) proposed that those manufacturers who are more concerned about the environment and who are proactive in their approach work to implement internal green supply chain management processes and activities and they tend to spread their supply chain partners externally. According to Wang et al. (2015) consumer behavior in an effective player for the promotion of environmentally friendly practices in the manufacturing industries, large companies face lots of pressure from its stakeholders for the improvement of their processes and practices and to contribute in the green environment. Customers' focus is considerably high in case of large organizations for the achievement of green supply chain practices and it is critical for the organizations to achieve high environmental performance regularly. Hall (2000) studied the customer behavior and concludes that customers are the vital source for implementation of green supply chain activities in an organization as the dominant customers pose a heavy pressure of their supplier to comply with environmental requirements and to work in green manner. Customers are in a strong position, due to the reason that they are considered as channel leaders, to influence the environmental practices, activities, policies and strategies of its suppliers and to enforce its suppliers to participate in green supply chain practices. As per the research conducted by Lee (2008) it was concluded that collaboration with the customers has become a fundamental characteristic for the organizations in United States to achieve environmentally friendly performance and effective collaboration with customers is a necessary component in green supply chain management.

\section{Conceptual Framework}

Internal green supply chain management refers to the intra-organizationally applied practices and the activities performed within the organization to make the processes performed by the organization more environmentally friendly (Klassen \& McLaughlin, 1996). Environmental collaboration with customers is type of external partnership and integration of an organization with its customers through which an organization targets to achieve environmental sustainability by working together with its customers (Walker et al., 2008). Environmental monitoring of suppliers is the fundamental characteristic of suppliers' evaluation by the organizations nowadays, it focuses to identify the suppliers that are more participative in environmental sustainability and that work in green supply chain manner (Chavez et al., 2014).

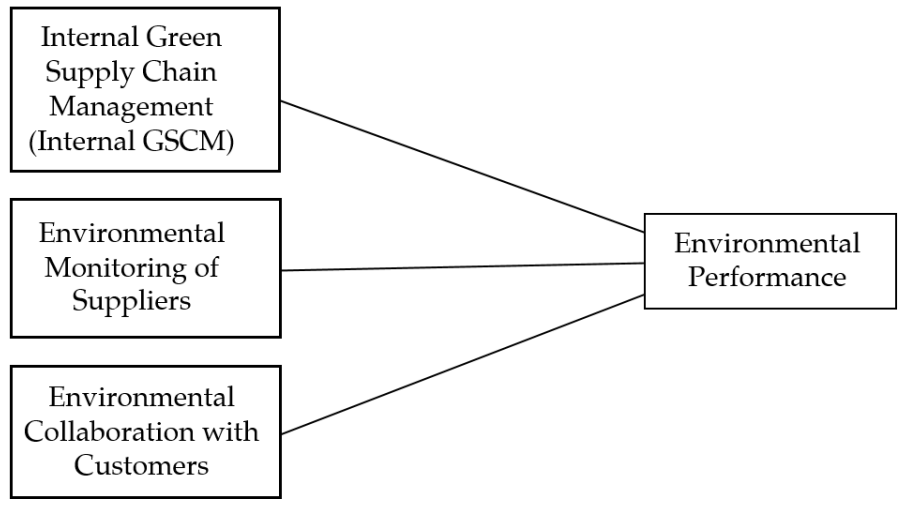




\section{Hypotheses}

Ha1: Internal Green Supply Chain Management has a significant impact of Environmental Performance of a firm.

$\mathrm{H}_{\mathrm{a} 2}$ : Environmental monitoring of suppliers has a significant impact of Environmental Performance of a firm.

$\mathrm{H}_{\mathrm{a} 3}$ : Environmental collaboration with the customers has a significant impact of Environmental Performance of a firm.

\section{Research Methodology}

\section{Sampling Design}

The target population for this research is the individuals working in various organizations in Pakistan especially individual pertaining to supply chain profession. Data has also been gathered from individual entrepreneurs involved in their businesses. The sample size of this study is 250; due to various issues including credibility, lack of availability and convenience and unknown population no statistical technique can be used to determine the size of sample (Sauders., 2009).

Convenience sampling method is used in this research for the gathering of data from targeted population. Convenience sampling technique is a non-probability technique of sampling.

\section{Procedure of Data Collection}

This study is based on primary data which will be collected through questionnaire. The instrument of data collection is Questionnaire. The questionnaire is constructed based on the developed scales adopted from (Laari et al, 2015). The questionnaire consists of closed ended questions. The questionnaire consists of 20 questions in all with 7 questions pertaining to Internal Green Supply Chain Management, 4 questions related to Environmental Monitoring of Suppliers, 3 questions for Environmental Collaboration with Customers and 6 questions pertaining to Environmental Performance. The questionnaire is being used to collect the data both physically and through electronic manners from the individuals working in Pakistan.

The questionnaire-based survey is developed on a 5 point Likert scale in the following scaling:

- $\quad$ Strong Disagree

- Disagree

- Neutral

- Agree

- Strong Agree.

In this chapter the data analysis and findings are discussed. The data collected through questionnaire from 250 respondents. Out of 250, 200 questionnaires were taken out as usable and were used for data analysis in this research. The first step before testing the hypothesis is to examine the demographic characteristics of data and the reliability analysis of the tool and the items used. In the second step to test the three-hypothesis correlation and regression analysis approach is used using SPSS software.

Table 1 present details related to the demographic factors. The demographic factors include experience, designation and education. From the table above, it observed that the manager contributed more in participating in this survey as compared to other designations. 
Table 1: Demographic Factors

\begin{tabular}{|l|l|l|l|}
\hline Profile & Categories & No & $\%$ \\
\hline \multirow{5}{*}{ Experience } & Less than 1 year & 23 & $12 \%$ \\
\cline { 2 - 4 } & $1-3$ years & 23 & $12 \%$ \\
\cline { 2 - 4 } & $4-6$ years & 45 & $23 \%$ \\
\cline { 2 - 4 } & $7-9$ years & 64 & $32 \%$ \\
\cline { 2 - 4 } & $10-12$ years & 36 & $18 \%$ \\
\cline { 2 - 4 } & $13-15$ years & 9 & $5 \%$ \\
\cline { 2 - 4 } & 16 years or more & 0 & $0 \%$ \\
\hline \multirow{5}{*}{ Education } & Executive/Officer & 23 & $12 \%$ \\
\cline { 2 - 4 } & Assistant Manager & 65 & $33 \%$ \\
\cline { 2 - 4 } & Manager & 98 & $49 \%$ \\
\cline { 2 - 4 } & Head of Department & 14 & $7 \%$ \\
\hline & Graduation & 40 & $20 \%$ \\
\cline { 2 - 4 } & Master & 146 & $73 \%$ \\
\cline { 2 - 4 } & M.Phil & 10 & $5 \%$ \\
\cline { 2 - 4 } & Phd & 4 & $2 \%$ \\
\hline
\end{tabular}

Among the total respondents who participated in this survey, $73 \%$ holds master's degree which indicates the high level of literacy of the participants. It is shown that most of the respondents have 7-9 years of experience in the field. Further details of the demographic distributions are explained in the table.

Table 2: Descriptive Analysis

\begin{tabular}{|l|l|l|l|l|l|l|l|l|l|l|l|l|}
\hline \multirow{2}{*}{ Questions } & \multicolumn{7}{|c|}{ Frequency } \\
\cline { 2 - 15 } & SA & A & N & D & SD & T & SA & A & N & D & SD & T \\
\hline $\begin{array}{l}\text { As an individual do you } \\
\text { appreciate the role of GSCM } \\
\text { Practices }\end{array}$ & 158 & 65 & 20 & 7 & 0 & 250 & 63 & 26 & 8 & 2.8 & 0 & 100 \\
\hline $\begin{array}{l}\text { Increases the use of } \\
\text { environmentally friendly } \\
\text { Raw material \& components. }\end{array}$ & 147 & 50 & 28 & 17 & 8 & 250 & 59 & 20 & 11 & 6.8 & 3.2 & 100 \\
\hline $\begin{array}{l}\text { We design our product in } \\
\text { such a way that it can be } \\
\text { recycled or reused }\end{array}$ & 162 & 45 & 12 & 24 & 7 & 250 & 65 & 18 & 4.8 & 9.6 & 2.8 & 100 \\
\hline $\begin{array}{l}\text { Being environmentally } \\
\text { friendly is a part of our } \\
\text { corporate culture }\end{array}$ & 144 & 66 & 32 & 7 & 1 & 250 & 58 & 26 & 13 & 2.8 & 0.4 & 100 \\
\hline $\begin{array}{l}\text { we plan the delivery of } \\
\text { company to minimize the } \\
\text { environmental impact }\end{array}$ & 177 & 53 & 19 & 0 & 1 & 250 & 71 & 21 & 7.6 & 0 & 0.4 & 100 \\
\hline $\begin{array}{l}\text { we use cross functional } \\
\text { cooperation to mitigate the } \\
\text { environmental impact }\end{array}$ & 183 & 43 & 20 & 4 & 0 & 250 & 73 & 17 & 8 & 1.6 & 0 & 100 \\
\hline $\begin{array}{l}\text { We use Green Marketing for } \\
\text { product promotion }\end{array}$ & 161 & 45 & 44 & 0 & 0 & 250 & 64 & 18 & 18 & 0 & 0 & 100 \\
\hline $\begin{array}{l}\text { We have used environmental } \\
\text { impacts as an essential } \\
\text { criterion in supplier selection. }\end{array}$ & 72 & 133 & 40 & 3 & 2 & 250 & 29 & 53 & 16 & 1.2 & 0.8 & 100 \\
\hline
\end{tabular}




\begin{tabular}{|c|c|c|c|c|c|c|c|c|c|c|c|c|}
\hline $\begin{array}{l}\text { We have asked our suppliers } \\
\text { for information on their } \\
\text { environmental compliance. }\end{array}$ & 62 & 120 & 55 & 11 & 2 & 250 & 25 & 48 & 22 & 4.4 & 0.8 & 100 \\
\hline $\begin{array}{l}\text { We have demanded our } \\
\text { suppliers to ensure the } \\
\text { environmentally friendly } \\
\text { practices of second-tier } \\
\text { suppliers }\end{array}$ & 14 & 138 & 38 & 44 & 16 & 250 & 5.6 & 55 & 15 & 18 & 6.4 & 100 \\
\hline $\begin{array}{l}\text { We have demanded our } \\
\text { suppliers to implement an } \\
\text { environmental management } \\
\text { system. }\end{array}$ & 44 & 134 & 50 & 14 & 8 & 250 & 18 & 54 & 20 & 5.6 & 3.2 & 100 \\
\hline $\begin{array}{l}\text { We have worked together } \\
\text { with our customers to take } \\
\text { environmental issues into } \\
\text { account in product design }\end{array}$ & 66 & 149 & 32 & 3 & 0 & 250 & 26 & 60 & 13 & 1.2 & 0 & 100 \\
\hline $\begin{array}{l}\text { We have developed our } \\
\text { deliveries to be more } \\
\text { environmentally friendly } \\
\text { with our customers }\end{array}$ & 70 & 134 & 33 & 12 & 1 & 250 & 28 & 54 & 13 & 4.8 & 0.4 & 100 \\
\hline $\begin{array}{lr}\text { Our company and our } \\
\text { customers have a clear mutual } \\
\text { understanding } & \text { of } \\
\text { responsibilities } & \text { in } \\
\text { environmental issues. } & \\
\end{array}$ & 112 & 103 & 30 & 5 & 0 & 250 & 45 & 41 & 12 & 2 & 0 & 100 \\
\hline $\begin{array}{l}\text { Carbon dioxide emissions } \\
\text { considering the volume of } \\
\text { production have decreased }\end{array}$ & 123 & 88 & 28 & 9 & 2 & 250 & 49 & 35 & 11 & 3.6 & 0.8 & 100 \\
\hline $\begin{array}{l}\text { Waste considering } \\
\text { volume of production } \\
\text { decreased }\end{array}$ & 98 & 99 & 47 & 6 & 0 & 250 & 39 & 40 & 19 & 2.4 & 0 & 100 \\
\hline $\begin{array}{l}\text { Energy consumption } \\
\text { considering the volume of } \\
\text { production has decreased }\end{array}$ & 60 & 70 & 65 & 44 & 11 & 250 & 24 & 28 & 26 & 18 & 4.4 & 100 \\
\hline $\begin{array}{l}\text { Water consumption } \\
\text { considering the volume of } \\
\text { production has decreased. }\end{array}$ & 111 & 79 & 45 & 10 & 5 & 250 & 44 & 32 & 18 & 4 & 2 & 100 \\
\hline $\begin{array}{l}\text { Consumption for hazardous } \\
\text { materials considering the } \\
\text { volume of production has } \\
\text { decreased }\end{array}$ & 152 & 70 & 22 & 4 & 2 & 250 & 61 & 28 & 8.8 & 1.6 & 0.8 & 100 \\
\hline $\begin{array}{l}\text { Compared to our competitors, } \\
\text { we have been a forerunner in } \\
\text { environmental issues. }\end{array}$ & 79 & 103 & 44 & 23 & 1 & 250 & 32 & 41 & 18 & 9.2 & 0.4 & 100 \\
\hline
\end{tabular}

In the result of Question no 1 we found that, $63 \%$ of the population seems strongly agree , $26 \%$ of the population is agree, $8 \%$ of them shows their neutral response $2.8 \%$ of them are disagree and none of them shows their interest of strongly disagree. Which shows that the majority of the population are positively agree on this question, similarly in the response of $2^{\text {nd }}$ question we found $59 \%, 20 \%, 11 \%, 6.8 \%$, and $3.2 \%$ of result respectively which shows that the around $79 \%$ of the population are positively agree, and in the response of the $3^{\text {rd }}$ question $65 \%, 18 \%, 4.5 \%, 9.6 \%, 2.8 \%$ respectively, which concluded us that majority of the manufacturing firms are shows their interest towards environment friendly products design, 
and the forth question lead us towards that the majority of the firm`s cooperate culture are in the favour of the environmental, further more in the next question draw our attention towards the use of GSCM practices in the delivery channels, similarly we got again a very positive response from the respondents, in the answer of thenext question we found that around $18 \%$ of the population are shows their interest towards Neutral, and rest are agree, from the next question we found that the huge population conceder GSCP and Environmental concern a basic factor in the selection of the suppliers, further more we found that the except some population again maximum of the keep the proper check and balance on their suppliers in the same regards, and further more similarly ask the same about their suppliers, means supplier`s supplier but here we find the some of them are not considering about it around $1 / 4$ of the total population and on the next level firms raise the demand, to build up the environmental management systems, and both firms and their suppliersboth work together to form that environmental products where majority of the population responded positively, on the next level studies finds that the majority of the respondents work on their deliveries to be more environmental friendly, now a day`s, both manufacturer as well as customers have enough knowledge regarding in this manner means environmental issues, which can be seen in the above table, again huge quantity of the respondents agrees that the visible number of carbon footprints decreases because of applying these practices , as well as volume of the waste also decreases, but on other hand we also found that there is a mix opinions in the use of energy after applying the green supply chain practices, but it makes the positive effects on use of water, these practices eliminates the use of hazardous raw material and products, and in the end we can clearly see that the upcoming competition in the market is going to be based on Environmental friendly products.

This research is based on exploratory data analysis through which an information can be analyzed thoroughly. It describes the essential features and characteristics of the data in order to get the evaluation of the data.

\section{QuAnTITATIVE TEChNIQUeS}

\section{Reliability and Exploratory Factor Analysis}

Reliability of the instrument is an essential element for the overall reliability of a research. The consistency of the items used in an instrument is calculated through reliability test. The table 3 of reliability analysis illustrate the items and Cronbach's alpha value of each independent and dependent variables in this research. The result indicates that Cronbach's Alpha values of all variables items range from are more than 0.5 which mean that all are significant and reliable for further process.

Table 3: Reliability statistics

\begin{tabular}{|l|c|c|}
\hline Variables & No. of items & Cronbach's alpha \\
\hline Internal Green Supply Chain & 7 & .832 \\
\hline Environmental Monitoring of suppliers & 4 & .814 \\
\hline Environmental collaboration with customers & 3 & .795 \\
\hline Environmental Performance & 6 & .827 \\
\hline
\end{tabular}

Exploratory factor analysis (EFA) is a statistical technique used in a research to identify underlying structure of large set of data and it is used to reduce large data into smaller set of variables. In this research exploratory factor analysis has been applied to figure out the most relevant questions for each variable studied in this research. 
Table 4 presents factor loading, that how each item loads into its relative principal component. Factor loading value of each item into its relative principal component should be greater than 0.40 . There are 7 components for supplier development, supply chain flexibility consists of 6 items and Supply Chain effectiveness is consist of 6 items. Factor loading values range from 0.441 to 0.820 . All cross loading values were ignored because of the value less than 0.40 . Overall, results of factor analysis satisfy the criteria of construct validity.

Table 4: Factor Analysis

\begin{tabular}{|c|c|c|c|c|}
\hline \multicolumn{5}{|l|}{ Rotated Component Matrix ${ }^{a}$} \\
\hline Items & 1 & 2 & 3 & 4 \\
\hline As an individual do you appreciate the role of GSCM Practices & .670 & & & \\
\hline Increases the use of environmentally friendly Raw material \& components. & .625 & & & \\
\hline We design our product in such a way that it can be recycled or reused & .671 & & & \\
\hline Being environmentally friendly is a part of our corporate culture & .627 & & & \\
\hline we plan the delivery of company to minimize the environmental impact & .717 & & & \\
\hline we use cross functional cooperation to mitigate the environmental impact & .739 & & & \\
\hline We use Green Marketing for product promotion & .705 & & & \\
\hline $\begin{array}{l}\text { We have used environmental impacts as an essential criterion in supplier } \\
\text { selection. }\end{array}$ & & .528 & & \\
\hline $\begin{array}{l}\text { We have asked our suppliers for information on their environmental } \\
\text { compliance. }\end{array}$ & & .685 & & \\
\hline $\begin{array}{l}\text { We have demanded our suppliers to ensure the environmentally friendly } \\
\text { practices of second-tier suppliers }\end{array}$ & & .852 & & \\
\hline $\begin{array}{l}\text { We have demanded our suppliers to implement an environmental } \\
\text { management system. }\end{array}$ & & .715 & & \\
\hline $\begin{array}{l}\text { We have worked together with our customers to take environmental } \\
\text { issues into account in product design }\end{array}$ & & & .845 & \\
\hline $\begin{array}{l}\text { We have developed our deliveries to be more environmentally friendly } \\
\text { with our customers }\end{array}$ & & & .812 & \\
\hline $\begin{array}{l}\text { Our company and our customers have a clear mutual understanding of } \\
\text { responsibilities in environmental issues. }\end{array}$ & & & .755 & \\
\hline $\begin{array}{l}\text { Carbon dioxide emissions considering the volume of production have } \\
\text { decreased }\end{array}$ & & & & .441 \\
\hline Waste considering the volume of production has decreased & & & & .749 \\
\hline Energy consumption considering the volume of production has decreased & & & & .733 \\
\hline Water consumption considering the volume of production has decreased. & & & & .828 \\
\hline $\begin{array}{l}\text { Consumption for hazardous materials considering the volume of } \\
\text { production has decreased }\end{array}$ & & & & .548 \\
\hline $\begin{array}{l}\text { Compared to our competitors, we have been a forerunner in } \\
\text { environmental issues. }\end{array}$ & & & & .828 \\
\hline \begin{tabular}{l|l} 
Extraction Method: Principal Component Analysis. \\
& Rotation Method: Varimax with Kaiser Normalization.
\end{tabular} & & & & \\
\hline
\end{tabular}

\section{Regression Analysis}

Regression analysis is a statistical technique which is commonly used in researches to identify the relationship between various variables studied in a research. It is used to identify the effect of independent variables on dependent variable. Regression analysis provides the researches with a typical value through which a dependent variable change by change in the independent variables. 
Table 5: Model Summary

\begin{tabular}{|c|c|c|c|c|c|}
\hline Model & $\mathrm{R}$ & R Square & Adjusted R Square & F & Sig. \\
\hline 1 & $.529^{\mathrm{a}}$ & .280 & .269 & 48.221 & $.000 \mathrm{~b}$ \\
\hline
\end{tabular}

Table 5 shows the outcome of model summary segment which shows the degree of goodness fit of regression model. The $\mathrm{R}$ value is (0.529), which shows that there is a moderate correlation among internal green supply chain management, environmental monitoring of suppliers, environmental collaboration with customers and environmental performance of a firm. The value of $\mathrm{R}^{2}$ is (0.280) which shows that only $28 \%$ of change in our dependent variable i.e. environmental performance is being resulted from the change in the independent variables. It can also be seen that Significance F value is less than 0.000 which shows that collective effect of all independent variable is significant.

Table 6: Estimated coefficients and the significance levels

\begin{tabular}{|c|c|c|c|c|c|c|}
\hline \multicolumn{7}{|c|}{ Coefficients $^{\mathrm{a}}$} \\
\hline \multirow{2}{*}{\multicolumn{2}{|c|}{ Model }} & \multicolumn{2}{|c|}{ Unstandardized Coefficients } & \multirow{2}{*}{$\frac{\text { Standardized Coefficients }}{\text { Beta }}$} & \multirow[t]{2}{*}{$\mathrm{T}$} & \multirow[t]{2}{*}{ Sig. } \\
\hline & & $\mathrm{B}$ & Std. Error & & & \\
\hline \multirow[t]{4}{*}{1} & (Constant) & .591 & .291 & & 2.029 & .060 \\
\hline & IGSCM & .420 & .150 & .351 & 2.794 & .000 \\
\hline & EMOS & .371 & .071 & .355 & 5.199 & .000 \\
\hline & ECWC & .395 & .110 & .352 & 3.455 & .000 \\
\hline
\end{tabular}

The results in Table 6 illustrates the estimated coefficients and the significance levels of all independent variables. For internal green supply chain management, environmental monitoring of suppliers and environmental collaboration with customers, it shows that the coefficient value (0.351); (0.355) and (0.352) respectively. Through significance value $p=.000$ it is being showed that internal green supply chain management, environmental monitoring of suppliers and environmental collaboration with customers have a positive and significant impact on the overall environmental performance of a firm. Therefore, it can be said that the finding of this research in Pakistan is in line with the finding of research done by (Laari, 2015), the research showed that internal green supply chain management, environmental monitoring of suppliers and environmental collaboration with customers have a significant and positive impact on the environmental performance of the organizations. According to the results obtained, regression equation is as follows:

$\mathrm{SCE}=0.591+0.420(\mathrm{IGSCM})+0.371(\mathrm{EMOS})+0.395(\mathrm{ECWC})+\mathrm{e}$

Here 0.591 is the value of constant, $0.420 ; 0.371$ and 0.395 are coefficients by which internal green supply chain management, environmental monitoring of suppliers and environmental collaboration with customers affects environmental performance.

\section{CONCLUSION}

Green supply chain management has become a critical aspect for all organization in the current era. This research study focuses to identify the relation and impact of various factors comprising of internal activities, customers and suppliers of the organizations with overall environmental performance of the organizations. This research paper not only analyzed the impact of internal green supply chain activities performed by organizations but also includes 
the external factors such as collaboration with customers and environmental monitoring of suppliers of the organizations. This study identifies the relations between customers' driven supply chain and green supply chain management and contributes to the researches going on around the world focusing on green supply chain management. The research hypotheses of this study were tested and analyzed using multiple linear regression and correlation among the variables and the major implications of this research are as under:

- Internal green supply chain activities are the most important characteristics for achieving environmental excellence for all organizations. According to the results found out in this study, it can be concluded that environmental performance of a firm can be improved by green supply chain activities within the organization. Organizations in Pakistan are working on various ways internally to achieve high environmental performance.

- Environmental monitoring of the suppliers is another important feature that has been studied in this research paper. It has been found out by the result of research that environmental monitoring of suppliers has a positive impact on the environmental performance of a firm. The firms that are working of green supply chain management critically monitors the performance of their suppliers. The environmental monitoring of suppliers is an important characteristic in supplier performance evaluation by the organizations.

- Another hypothesis that has been tested in this research study is the relationship of environmental collaboration with customers and environmental performance of a firm. It has been found in this research that collaboration with customers also positively affect the environmental performance of a firm. Various activities are performed by the organizations to collaborate with their customers so as to be able to achieve high environmental performance. One of the examples of such collaboration with customers is reverse logistics activities performed by the organizations.

The result of this research validates the result of the research made by (Laari et al, 2015). According to the research conducted by Laari et al., (2015), internal green supply chain management, environmental collaboration with customers and environmental monitoring of suppliers positively affect the overall performance of a firm.

This research study provides the organizations with the basis to practice green supply chain management in Pakistan to enhance their environmental performance, moreover, it is important for the organizations to identify the areas through which environmental sustainability can be achieved. The results of this research indicate that all variables studied in this research including internal green supply chain management, environmental collaboration with customers' and environmental monitoring of suppliers' positively affect the overall environmental performance of a firm. An organization can enhance its environmental performance by effectively applying the strategies for green supply chain management. Green supply chain management has become a critical aspect in the current era as it has emerged as most vital attribute to sustainable environment.

\section{Limitations}

This research study focused on few variables that affect the environmental performance of the organization. Furthermore, the population studied in this research is more from manufacturing industry of Pakistan. Therefore, many other variables can be studies in 
pursuance of analyzing environmental performance of organization. Population for the research can be extended to other industry operating in Pakistan. Another limitation of this research is that it is conducted in Karachi only. Therefore, a research in other areas of Pakistan is also possible to evaluate the environmental performance of the organizations affecting by customers' driven green supply chain.

\section{REFERENCES}

Chan, R.Y.K. and Lau, L.B.Y. (2001), "Explaining green purchasing behavior: a cross-cultural study on American and Chinese consumers", Journal of International Consumer Marketing, Vol. 14 Nos. 2/3, pp. 9-41.

Chavez, R., Yu, W., Feng, M., Wiengarten, F., 2014. The effect of customer-centric green supply chain management on operational performance and customer satisfaction. Bus. Strat. Environ. in press

Christmann, P. and Taylor, G. (2001), "Globalization and the environment: determinants of firm selfregulation in China", Journal of International Business Studies, Vol. 32 No. 3, pp. 439-58.

Hall, J., 2000. Environmental supply chain dynamics. J. Clean. Prod. 8(6), 455-471.

Houdré, H. 2008. Sustainable hospitality@: Sustainable development in the hotel industry. Cornell Hospitality Industry Perspectives 1 (2): Cornell Center for Hospitality Research.

Kassinis, G., and A. Soteriou. 2003. Greening the service profit chain: The impact of environmental management practices. Production and Operations Management 12 (3): 386-403.

Klassen, R.S., McLaughlin, C.P., 1996. The impact of environmental management on firm performance. Manage. Sci. 42(8), 1199-1214

Laari S, Töyli J, Solakivi T, Ojala L, Firm performance and customerdriven green supply chain management, Journal of Cleaner Production (2015),

Lee, S.-Y., Klassen, R.D., Furlan, A., Vinelli, A., 2014. The green bullwhip effect: Transferring environmental requirements along a supply chain. Int. J. Prod. Econ. 156, 39-51

McKercher, B., and B. Prideaux. 2011. Are tourism impacts low on personal environmental agendas? Journal of Sustainable Tourism 19 (3): 325-45.

Md. Saifur Rahman, Md. Hasan Ali, A.S.M. Tariq Hoque( 2017 ), International Conference on Mechanical, Industrial and Materials Engineering 2017 (ICMIME2017), 28-30 December, 2017, RUET, Rajshahi, Bangladesh.

Preuss, L. (2001), "In dirty chains? Purchasing and greener manufacturing", Journal of Business Ethics, Vol. 34 No. 3 and 4, pp. 345-59.

Sarkis, A. 2003. Strategic decision framework for green supply chain management. Journal of Cleaner Production 11:397-409.

Sarkis, J. and Kitazawa, S. (2000), "The relationship between ISO 14001 and continuous source reduction programs", International Journal of Operations \& Production Management, Vol. 20 No. 2, pp. 22548.

Sauders, T. \&. (2009). Research Methods For Business Students.

Seyfang, G., and A. Smith. 2007. Grassroots innovations for sustainable development: Towards a new research and policy agenda. Environmental Politics 16 (4): 584-603.

Sheth, J., N. Sethia, and S. Srinivas. 2011. Mindful consumption: A customer-centric approach to sustainability. Journal of the Academy Marketing Science 39:21-39

Sigala, M. 2012. Exploiting web 2.0 for new service development: Findings and implications from the Greek tourism industry. International Journal of Tourism Research 14:551-66.

Syed Abdul Rehman Khan1 \& Dong Qianli (2017), Environ Sci Pollut Res (2017) 24:16829-16844 
UbaidullahMumtaz ,Yousaf Ali, Antonella Petrillo (2018),A linear regression approach to evaluate the green supply chainmanagement impact on industrial organizational performance. Science of theTotalEnvironment 624 (2018)162-169

Wagner, M. 2012. Entrepreneurship, innovation and sustainability. Sheffield, UK: Greenleaf.

Walker, H., Di Sisto, L., McBain, D., 2008. Drivers and barriers to environmental supply chain management practices: Lessons from the public and private sectors. J. Purch. Supply Manag. 14(1), 69-85.

Wang, Z., Wang, C., Yin, J., 2015. Strategies for addressing climate change on the industrial level: affecting factors to $\mathrm{CO} 2$ emissions of energy intensive industries in China. Nat. Hazards 75(2), 303317

Yu CS (2002) A GP-AHP method for solving group decision-making fuzzy AHP problems. Comput Oper Res 29(14):1969-2001.

Yu, W., Chavez, R., Feng, M., Wiengarten, F., 2014. Integrated green supply chain management and operational performance. Supply Chain Manag. Int. J. 19(5/6), 683-696

Zhu, Q., Sarkis, J., Lai, K. 2013. Institutional-based antecedents and performance outcomes of internal and external green supply chain management practices. J. Purch. Supply Management. 19(2), 106117

Zhu, Q., Sarkis, J., Lai, K., 2012. Examining the effects of green supply chain management practices and their mediations on performance improvements. Int. J. Prod. Res. 50(5), 1377-1394.

$$
--0--
$$

